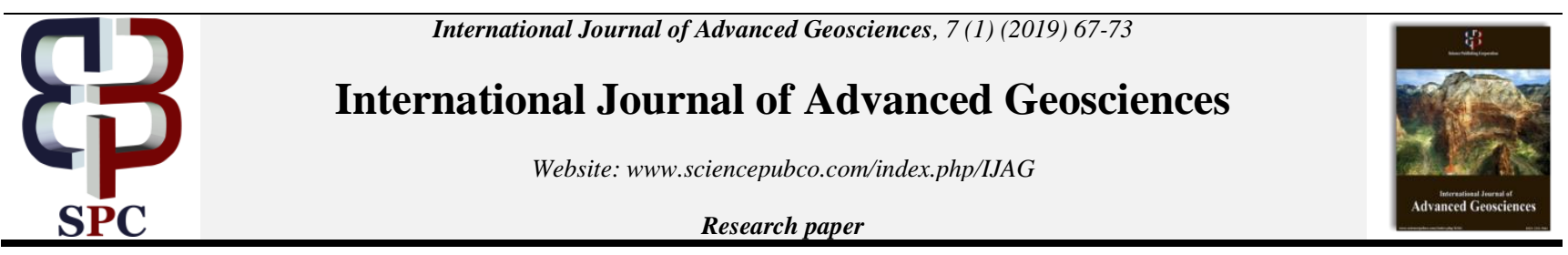

\title{
Evaluation of groundwater supply potential from hydraulic parameters estimated from vertical electrical sounding (VES) in Ikeduru, south east Nigeria
}

\author{
Nwosu Jacinta Chiemela ${ }^{1 *}$, Leonard I Nwosu ${ }^{2}$, Godwin O Chukwu ${ }^{3}$ \\ ${ }^{1}$ Michael Okpara University of Agriculture, Umudike \\ ${ }^{2}$ University of Portharcourt, Choba \\ *Corresponding author E-mail: jacintanwosu@gmail.com
}

\begin{abstract}
A Vertical Electrical resistivity Sounding (VES) survey was carried out, to study the groundwater supply potential, protective capacity and soil corrosivity of aquifers in Ikeduru Local Government Area of Imo state, Nigeria. A total of ten (10) geoelectric soundings were acquired. Schlumberger electrode configuration was used in acquiring the data. Six to seven geoelectric layers were delineated from the interpreted results, the Aquifers were delineated between the fifth and sixth geoelectric layers, having an apparent resistivity above $1000 \Omega \mathrm{m}$, with the highest thick of $69.0 \mathrm{~m}$ at a depth of $144.0 \mathrm{~m}$. Longitudinal Conductance, Hydraulic Conductivity, Transmissivity and Product Conductance range are as followings for the aquifers; $1.720-127.000 \times 10-3 \Omega-1,15.90-188.79 \mathrm{~m} / \mathrm{day}, 1093.3-1097.1 \mathrm{~m} 2 / \mathrm{day}$ and $2.590-252.50 \times 10-3$ respectively. Inferring from our hydraulic parameters, all the aquiferous zones have very high designation, wwithdrawal of great regional importance of groundwater supply potential and practically noncorrosive, soil corrosivity. $40 \%$ percentage of the aquiferous units have very good protective capacity, while for excellent and good protective capacity of the study are is $30 \%$. All the VES points are said to be a very viable potential for safe source for groundwater exploration.
\end{abstract}

Keywords: Corrosivity; Groundwater Supply; Hydraulic and Product Conductivity; Transmissivity.

\section{Introduction}

Groundwater happens to be a more reliable source of water, for over the half of the world population (Alabi et al., 2010; Anomohanran, 2011), and is explained as that part of precipitation that enters the ground and percolates downward through unconsolidated materials and openings in bedrock until it reaches the water table. This unconsolidated sediment that is capable of yielding water in usable quantities is referred to as aquifer (Alabi et al., 2010). Aquifer properties which are known to affect groundwater availability include aquifer thickness and the size and degree of interconnection of pore spaces within the aquifer material. These properties affect the ability of an aquifer to store and transmit groundwater. In order to explore these natural resources, for the benefit of man, various geophysical methods have been employed successfully. These methods include electrical resistivity, seismic refraction, electromagnetic, gravity, magnetic and magnetulluric (Karani et al., 2009; Majumdar and Das, 2011; Todd, 2004). The choice of method depends largely on the depth of investigation and sometimes the cost (Todd, 2004) of all these methods used in exploring ground water, the electrical resistivity profiling method has been the most widely used method. This is because the resistivity of rocks is sensitive to its ionic content (Alile et al., 2011). And operation of the instrument is uncomplicated and the analysis of data is economical (Ezeh and Ugwu, 2010; Anomohanram, 2011; Atakpo and Ofomola, 2012). The electrical resistivity method is used to estimate the depth of the bedrock surfaces and the soil or rock thickness (Nwankwo, 2011). The method is also used to investigate ground water contaminant and their movement pattern (Ehirim and Ofor, 2011).

Vertical electric sounding (VES) has proved to be effective in solving groundwater problems in most places in Nigeria (Onuoha and Mbazi, 1988; Mbonu et al., 1991; Mbipom et al., 1996; Ekine and Osobonye, 1996; Eze and Ugwu, 2010). In the present study, an attempt had been made to establish the aquifer characteristics in study area

\section{Geology and hydrogeology of the study area}

Ikeduru local government area, which is in the humid tropics with over 2,000 mm Of rainfall per annum and a mean annual temperature of about $27^{\circ} \mathrm{C}$ (Onyenechere, 2011). The Rainy season commences in March/April and ends in October/November (Onyenechere, 2011). The area is drained by series of rivers and streams namely, Mbaa, Oramiriukwa, and Okatankwo rivers. These are the major water resources in the area. The distributaries and Tributary of these rivers effectively drain the area. These rivers are also characterized by dry valleys which are usually covered by flood water during periods of high rainfall. Flood water infiltration during the rainy season recharges the aquifer. 
The study area is located in the Benin formation which is by far the most aquiferous unit, consisting mainly of massive continental sands, sandstones, and gravels. It has a very extensive deep unconfined aquifer which covers more than half of the Imo River Basin. The aquifer consists of thick complex interbedded units of fine, medium and coarse-grained quartz sands and gravels (Uma, 1989).

The Benin formation is characterized by an equatorial climate with an abundant rainfall that feeds an extensive hydrological system, having an average annual rainfall of about $2000 \mathrm{~mm}$ (Onwuegbuche, 1993). The impermeability of the subsurface formation of the north east has led to a development of a complex networks of rivers draining towards the cross river. In the southwest part of the state, the high permeability of the underlying coastal plain sands has for the most part prevented the development of a stream network. However, this highly permeable formation is underlain by impervious strata making the whole western part a vast aquifer and plentiful source of groundwater (Nwosu et al., 2013).

The three main regional aquifers are identified in Imo state

1) The Coastal plain sands

2) The Bende - Ameki group (part of Anambra basin)

3) The Ajalli formation

The coastal plain sand that covers the study area underlie almost half of the state and has an annual replenishment of about 2.5 billion cubic meters per year. It is built of alternating layers of sands, sandstones, and seams of clays. As the sandy component in most areas forms more than $90 \%$ of the sequence of layers, permeability, transmissivity, and storage coefficients are high (Nwosu et al., 2013). The northern boundary of this hydrological province in eastern Nigeria adjoins the Anambra and the cross rivers basins.

The coastal sedimentary lowlands are underlain by the tertiary sediments of the deltaic plain, the coastal plain sand, the Bende Ameki and the Imo shale. With the exception of the Imo shale, most of the formations consist of predominantly unconsolidated sands that are porous; the high yearly average rainfall over the area ensures adequate ground water recharge.

Groundwater occurs in essentially unconfined conditions over most of the area. The depth to the aquifer vary from a few feet in the south to maximum of $501 \mathrm{ft}(152.7 \mathrm{~m})$ with average depth of $150 \mathrm{ft}(45.7 \mathrm{~m})$ below the ground surface (Ayoade, 1995).

On the other hand the depth of water table in Bende Ameki is often considerable, reaching as much as 587ft (178.9m) (Ayoade, 1995). The Bende Ameki group is composed mainly of sands intercalated with shales, lignites and calcareous shales. The sand parts have more or less the same coefficients of permeability as coastal plain sands. But the transmissivity coefficient is lower because of high percentage of shales.

The Ajalli formation extends through the north eastern parts of the state and dips towards the south west. The rate of replenishment is about 250 million cubic meters per year. When compared with the other formations, it is the least prolific for groundwater (Nwosu et al., 2013).

There are other local aquifers which include the Alluvium, upper coal measures and Nkporo - Ezeagu formation. The main aquifers have very high rate of replenishment per annum, the most being the coastal plain sands.

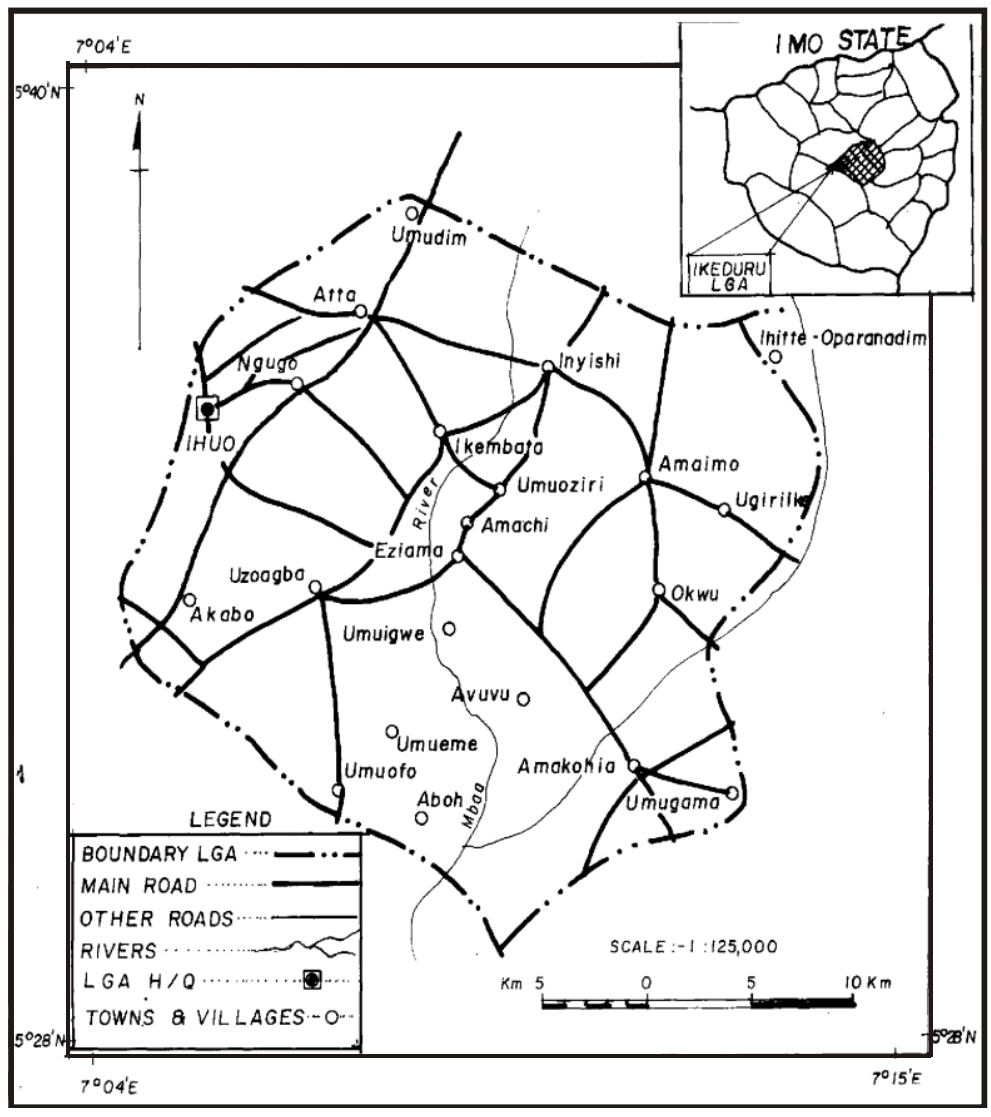

Fig. 1: Map of Ikeduru Local Government Area of Imo State. 


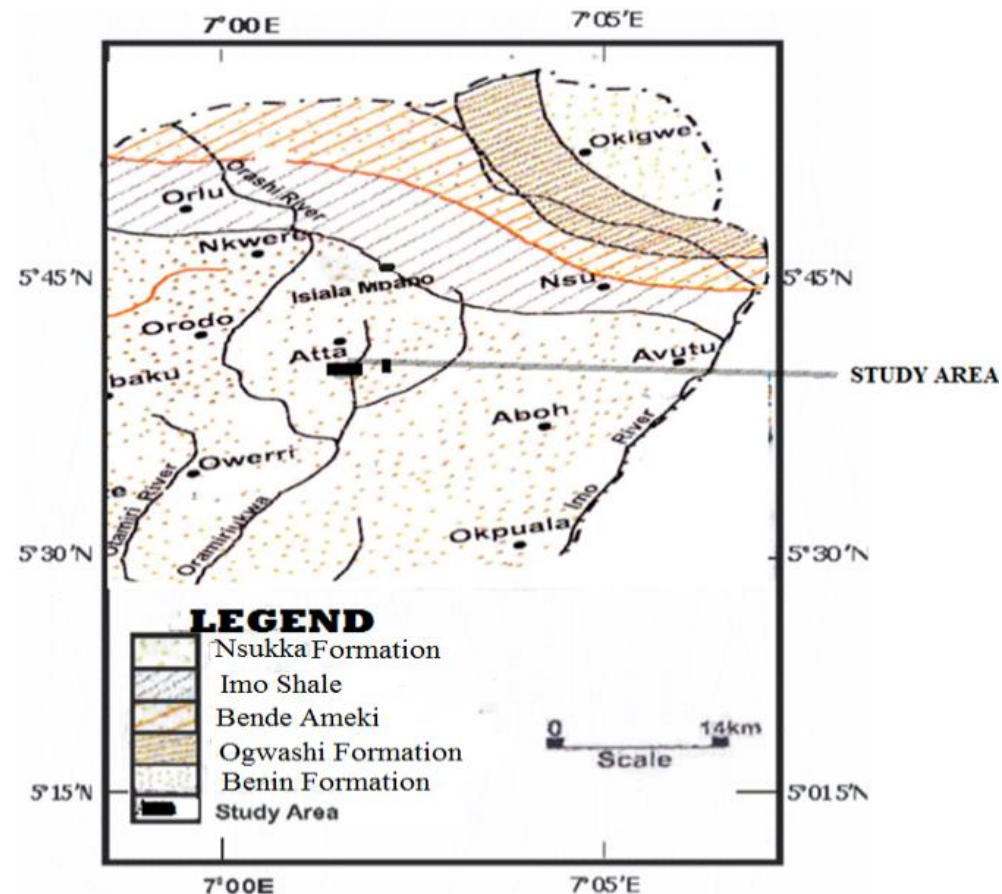

Fig. 2: Geological Map of Parts of Imo State Showing Study Area (Adapted From Akolisa and Selemo 2009 as in Nwosu Et Al., 2013)

\section{Materials and methods}

Electrical resistivity studies in geophysics may be understood in the context of current flow through a subsurface medium consisting of layers of materials with different individual resistivities. For simplicity, all layers are assumed to be horizontal. The resistivity $\rho$ of a material is a measure of how well the material retards the flow of electrical current. The resistivity varies tremendously from one material to another. Due to this great variation, measuring the resistivity of an unknown material has the potential for being very useful in identifying that material, given little further information. In field studies, the resistivity of a material may be combined with reasoning along geologic lines to identify the materials that constitute the various underground layers.

\subsection{Geoelectric parameters}

The two major parameters that can be used to describe a geo-electric layer are the resistivity $\rho$, and thickness h, of the layer. Other parameters include: the longitudinal conductance given by the equation

$\mathrm{s}=\frac{\mathrm{h}}{\rho}=\mathrm{h} \sigma 1$

The transverse resistance given by the equation

$\mathrm{R}=\mathrm{h} \rho 2$

Where, $\sigma$ is the electrical conductivity. The layer transmissivity is used in ground water studies (Nwosu et al, 2013). It is given by the equation

$T=K h 3$

Where, $K$ is the hydraulic conductivity

Niwas and Singhal (1981) derived analytically the relationship between $\mathrm{T}$ and $\mathrm{S}$ as follows

$T=K \sigma R=\frac{K S}{\sigma}=K h 4$

They showed that in areas where the geologic settings and water quality do not vary greatly, the product $K \sigma$, remain fairly constant. Hence if the values of $K$ from the existing boreholes and $\sigma$ from the sounding interpretations around the boreholes are available, it is possible to estimate the transmissivity and its variation from place to place to determine $\mathrm{R}$ or $\mathrm{S}$ for the aquifer.

\subsection{Aquifer parameters}

\subsubsection{Specific yield}

This is the volume of water, expressed as a percentage of the total volume of the saturated aquifer that can be drained by gravity. The volume retained (by molecular and surface tension forces) against the force of gravity, expressed as a percentage of the total volume of the saturated aquifer, is called the specific retention.

porosity $=$ specific yield + specific retention 5 
Specific yield can be determined in the laboratory by simple saturation and drainage, while in the field by pumping a known volume of water out and determining the volume of sediments drained by observing the depth of the water lowered.

specific yield $=\frac{\text { volume of water pumped out }}{\text { volume of sediments drained }} \times 1006$

\subsubsection{Hydraulic conductivity (K)}

Hydraulic conductivity $K$ is the specific discharge $V$ per unit hydraulic gradient $\frac{d h}{d l}$ at a specified temperature and expresses the ease with which fluid is transported through a porous matrix.

$K=\frac{V}{\frac{d h}{d l}} 7$

Where $V=\frac{Q}{A}$, is therefore a coefficient which depends on both matrix and fluid properties. The relevant fluid properties are density $\rho$ and viscosity $\mu$ (or in the combined form of kinematic viscosity $v$ ). The relevant solid matrix properties are mainly grain (or pore) size distribution, shape of grains, arrangement of pores and porosity.

$K=\frac{k \rho g}{\mu}=\frac{k g}{v} 8$

Where $K$ (dimensions of $L^{2}$ ) is called the permeability or intrinsic permeability of the porous matrix which depends solely on properties of the soil matrix.

Field measurements of hydraulic conductivity are usually made by carrying out pumping test on wells while laboratory measurements are done using parameters.

\subsubsection{Transmissivity (T)}

$T=K h 9$

Where $K$, is the hydraulic conductivity and $\mathrm{h}$ is the thickness of the aquifer. Transmissivity $\mathrm{T}$ defines the rate at which water of prevailing kinematic viscosity is transmitted through a unit width of the aquifer under a unit hydraulic gradient.

\subsubsection{Storage coefficient (storativity)}

This defines the volume of water that an aquifer releases from or takes into storage per unit surface area of aquifer per unit change in the component of head normal to that surface. It is a dimensionless quantity involving a volume of water per volume of aquifer.

$S=\frac{Q}{A \frac{d h}{d l}} 10$

In an unconfined aquifer, the storage coefficient varies from 0.05 and 0.3 and approximates the specific yield (water yielded from the saturated sand under gravity).

In a confined aquifer where no dewatering of the aquifer occurs, the volume of water released for unit decline of water table may be attributed to the compression of the water bearing material and the expansion of the water itself. It varies between 0.00005 and 0.005 .

An aquifer is homogeneous if its hydraulic properties are same at all points. Otherwise, it is heterogeneous. If the hydraulic properties are independent of direction, the aquifer is isotropic. Otherwise, it is anisotropic.

\section{Result and analysis}

All field data was subjected to manual computation and finally to computer processing techniques, applying the Schlumberger computer automatic analysis package and the Advanced Geophysics Incorporation (AGI) 1D resistivity analytical software for the interpretations of apparent resistivity curves which assumes horizontal layering of the earth with defined thickness and resistivity. The most common tool for interpreting resistivity data for a small number of horizontal layers is the assemblage of master curves. Each of such curves is a plot of apparent resistivity versus half current electrode spacing $(\mathrm{AB} / 2)$ on a log-log graph scale for the chosen electrode configuration and for a specified layering configuration, with various thickness and resistivity ratios being assumed for the individual layers. Usually there are two, three and four master curves for the interpretation of the VES curves using the Schlumberger electrode configuration.

The sounding curves obtained from the data acquired from the study area are generally 6 to 7 layers geoelectric layers. The model curves are a combination of the $\mathrm{AK}$ and $\mathrm{QH}$ Curve types. These results were correlated with existing Lithologic logs from some boreholes in the area.

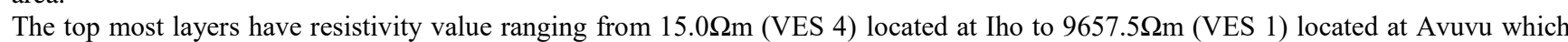

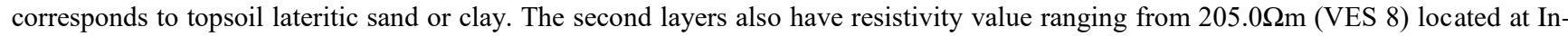
yishi, which correspond to the sand, medium coarse sand and sandstone in some parts of the study area. The third layers also have a resistivity value ranging from $244.3 \Omega \mathrm{m}$ (VES 2) located at Atta, which correspond to fine sand, medium coarse sand and sandstone in some locations like (VES 7). The fourth layers have resistivity value ranging from $104.8 \Omega \mathrm{m}$ (VES 4) located at Iho, which corresponds to clayey sand at VES 4, sand, medium coarse sand and sandstone in some locations. The fifth layers have resistivity value ranging from 252.0 $\Omega \mathrm{m}$ (VES 4) located at Iho to $14342.0 \Omega \mathrm{m}$ (VES 8) located at Inyishi, which corresponds to sandstone, medium coarse sand and sand in some part of the study area. The sixth layers have resistivity ranging from $0.2 \Omega \mathrm{m}$ (VES 4) located at Iho, which corresponds to clay (VES 4 and 5), sand, medium coarse sand and sandstone. However, the seventh layers have resistivity value ranging from $1424 \Omega \mathrm{m}$ (VES 7) located at Ikembara which corresponds to mostly clay, sand and sandstone (VES 7). 
The aquiferous layers were delineated by comparing the geoelectric section with the pumping test data static water level, thus the aquiferous zones are encountered in the sixth layer at VES 1, 2, 7, 8, 9, and 10 and fifth Layer at VES 3, 4, 5 and 6, which has high resistivity value higher than $1000 \Omega \mathrm{m}$ excerpt for $\operatorname{VES}(4,5$ and 7$)$ less than $1000 \Omega \mathrm{m}$.

This high resistivity values may be attributed to the predominance of sand/medium coarse sand and sandstone.
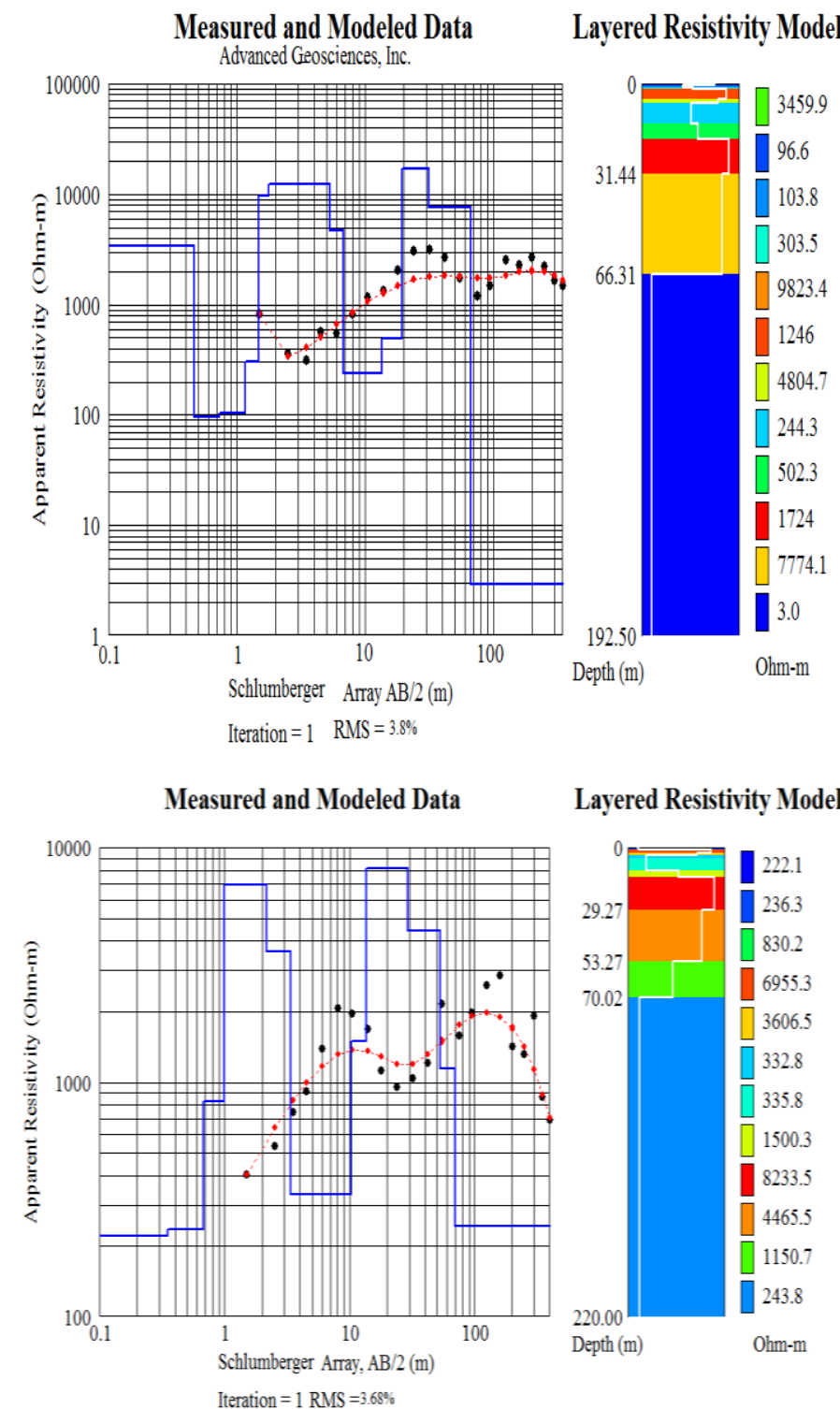

Layered Resistivity Model

Fig. 3: Computer Interpreted of VES 2 and 3.

Depth variations of the aquiferous zones are observed in the study area. It was observed that VES 7 and 8 at the locations Ikembara, Inyishi and Amachi have high depth values with VES 7 having the highest depth value of $144 \mathrm{~m}$ and thickness of $69.0 \mathrm{~m}$ which is the most saturated zone and is located at the northern part of the study area. The resistivity shows variation in resistivity of the aquiferous zones in the study area which shows that the study area has moderately high resistive aquifer materials as, with high values recorded at VES 1, 2 and 8 with values from $7774 \Omega \mathrm{m}$ (VES 2) to $9695 \Omega \mathrm{m}$ (VES 1), which are observed in the northern part of the study area.

The variation of resistivity of the depth investigated with electrode spacing is due to the difference in geology, topography, water quality and degree of saturation.

Aquifer potential is dependent on the thickness. As observed, VES 2, 3, 5, 7 and 8, have high thickness with VES (7) located at Ikembara having the highest thickness of $69.0 \mathrm{~m}$ making it more viable and prolific with depth value of 144m. While VES 1 and 6 have thin thickness.

The Isopach map shows the distribution of aquifer thickness in the study area. Ikembara (VES 7) in the northern part of the study area has the highest thickness and VES 8 located at Inyishi recorded $48.7 \mathrm{~m}$ and all lies within the northern part of the study area.

Longitudinal conductance is the ratio of thickness (h) to resistivity in per Ohm, it emphasizes on the longitudinal distributions of the aquifer geomaterials within the area under examination The variation in longitudinal conductance ranges from $1.720 \times 10^{-3}$ (VES 1 ) located at Umudim with a relative thickness of $16.70 \mathrm{~m}$ to $127.8 \times 10^{-3}$ and $112.6 \times 10^{-3}$ (VES 5 and 7) located at Akabo and Ikembara with thicknesses of $34.00 \mathrm{~m}$ and $69.00 \mathrm{~m}$ (Table 4.1). Areas with high longitudinal conductance values are good prospects for drilling boreholes while areas with low values may not be good enough for drilling boreholes with high yield expectation. These lower values are diagnostic of places with high values of resistivities, whose thicknesses are relatively small.

This is the product of hydraulic conductance, $\mathrm{k}$ and the aquifer thickness, h. The transmissivity of the aquiferous zone as shown in table 4.1, the values are fairly homogenous with little variation. The values ranged from $1093.30 \mathrm{~m} /$ day (VES 10) located at Amaimo with aquifer thickness of $7.20 \mathrm{~m}$ to $1097.10 \mathrm{~m} /$ day (VES 7) located at Ikembara with aquifer thickness of $69.00 \mathrm{~m}$. However, the transmissivity which is relatively high is characteristic of the Benin formation made up of the coastal plain sands. The high and homogenous nature of 
the transmissivity values coupled with the relatively high longitudinal conductance values makes the entire Ikeduru Area viable for drilling water borehole with high yield expectation.

The hydraulic conductivity, K calculated from the VES data ranged from 15.87m/day (VES 7) located at Ikembara to 188.79m/day (VES 6) located at Uzoagba.

Table 4.1: Geoelectric and Hydraulic Parameters of the Aquifers

\begin{tabular}{|c|c|c|c|c|c|c|c|c|c|}
\hline VES & Location & $\begin{array}{l}\text { Depth } \\
\text { (m) }\end{array}$ & $\begin{array}{l}\text { Resistivity of } \\
\text { Aquifer } \\
\text { Layer }(\Omega \mathrm{m})\end{array}$ & $\begin{array}{l}\text { Thickness } \\
\mathrm{h}(\mathrm{m})\end{array}$ & $\begin{array}{l}\text { Longitudinal } \\
\text { conductance } \\
\left(\Omega^{-1}\right) \times 10^{-3}\end{array}$ & $\begin{array}{l}\text { Transverse } \\
\text { Resistance R } \\
\left(\Omega \mathrm{m}^{2)}\right.\end{array}$ & $\begin{array}{l}\text { Hydraulic } \\
\text { Conductivity K } \\
\text { (m/day) }\end{array}$ & $\begin{array}{l}\text { Transmisisvity } \\
\mathrm{T}\left(\mathrm{m}^{2} / \text { day }\right)\end{array}$ & $\begin{array}{l}\text { Product Con- } \\
\text { ductivity } \mathrm{K} \sigma \\
\left(\mathrm{x} 10^{-3}\right)\end{array}$ \\
\hline 1 & Umudim & 62.70 & 9695.0 & 16.70 & 1.720 & 161906.5 & 65.57 & 1095.0 & 6.75 \\
\hline 2 & Atta & 66.30 & 7774.1 & 34.90 & 4.489 & 271316.1 & 31.40 & 1096.3 & 4.05 \\
\hline 3 & Ngugo & 53.37 & 4465.5 & 24.00 & 5.375 & 107172.0 & 45.63 & 1095.1 & 10.20 \\
\hline 4 & Iho & 51.71 & 252.0 & 17.22 & 68.330 & 4339.4 & 63.59 & 1095.0 & 252.50 \\
\hline 5 & Akabo & 59.16 & 266.0 & 34.00 & 127.800 & 9054.6 & 32.20 & 1096.0 & 120.96 \\
\hline 6 & Uzoagba & 32.60 & 1533.2 & 5.80 & 3.783 & 8892.6 & 188.79 & 1095.0 & 123.10 \\
\hline 7 & Ikembara & 144.00 & 613.0 & 69.00 & 112.600 & 42297.0 & 15.90 & 1097.1 & 25.90 \\
\hline 8 & Inyishi & 77.70 & 8706.8 & 48.70 & 5.593 & 424021.2 & 22.50 & 1096.9 & 2.590 \\
\hline 9 & Ugirike & 75.00 & 2495.0 & 23.52 & 9.427 & 58682.4 & 46.56 & 1095.1 & 18.70 \\
\hline 10 & Amaimo & 59.00 & 1437.0 & 7.20 & 5.010 & 10346.4 & 151.80 & 1093.3 & 105.80 \\
\hline
\end{tabular}

Table 4.2: Interpretation of the Aquifers from Their Hydraulic Parameters

\begin{tabular}{lllll}
\hline VES & Designation & Groundwater Supply Potential & Protective Capacity Rating & Soil Corrosivity \\
\hline 1 & Very high & Withdrawal of great regional importance & Good & Practically noncorrosive (PNC) \\
2 & Very high & Withdrawal of great regional importance & Good & Practically noncorrosive (PNC) \\
3 & Very high & Withdrawal of great regional importance & Very good & Practically noncorrosive (PNC) \\
4 & Very high & Withdrawal of great regional importance & Excellent & Practically noncorrosive (PNC) \\
5 & Very high & Withdrawal of great regional importance & Excellent & Practically noncorrosive (PNC) \\
6 & Very high & Withdrawal of great regional importance & Good & Practically noncorrosive (PNC) \\
7 & Very high & Withdrawal of great regional importance & Excellent & Practically noncorrosive (PNC) \\
8 & Very high & Withdrawal of great regional importance & Very good & Practically noncorrosive (PNC) \\
9 & Very high & Withdrawal of great regional importance & Very good & Practically noncorrosive (PNC) \\
10 & Very high & Withdrawal of great regional importance & Very good & \\
\hline
\end{tabular}

The conductivity product $\mathrm{K} \sigma$ of the aquiferous zones were determined. The conductivity product $\mathrm{K} \sigma$ range between $2.590 \times 10^{-3}$ (Inyishi) to $252.50 \times 10^{-3}$ (Iho). The slight variation may arise from the nature of the depositional environment according to Niwas and Singhal

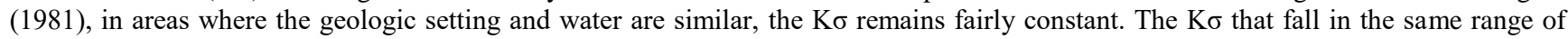
value showed that each of these zones has the same geologic setting and water quality.

Groundwater potential evaluation of an area can be based on the characteristic aquifer geoelectrical parameters obtained from VES interpretation results and borehole hydrogeological information (Olorunfemi et al., 1999).

\section{Conclusion}

The geophysical investigation involving the use of vertical electrical sounding (VES) using Schlumberger electrode configuration, carried out in Ikeduru Local Government Area of Imo state, Nigeria in conjunction with the borehole information from pumping test data have been used to develop the following conclusions;

- The aquiferous layers in the study area have been delineated.

- The aquiferous layers are composed of moderately high aquifer materials.

- The aquifer characteristics such as hydraulic conductivity, longitudinal conductance and transmissivity of the aquiferous zones have been successfully determined.

- The depth to aquifer or water table in Ikeduru local government area of Imo state, have been delineated.

- Areas around Amaimo, Iho and Uzoagba have been mapped out as promising for siting water boreholes with high yield expectations.

\section{References}

[1] Akaolisa, C.C.Z. and Selemo, A.O.I. (2009): A Study of the Sand and Gravel Deposit Around the Permanent Site of the Federal University of Technology, Owerri using the Vertical Electrical Sounding (VES) Techniques; Nigeria Journal of Physics, 21:81- 88.

[2] Alabi, A.A., Bello, R., Ogungbe, A.S. and Oyerinde, H.O. (2010): Determination of ground water potential in Lagos State University, Ojo using geoelectric methods (vertical electrical sounding and horizontal profiling); Report Opinion, 2: 68-75.

[3] Alile, O.M., Amadasun, C.V.O. and Evbuomwan, A.L. (2008): Aplication of Vertical Electrical Sounding Method to Decipher the Existing Subsurface Stratification and Groundwater Occurrence Status in a Location in Edo North of Nigeria. Int. J. Phys. Sci., 3(10): 245-249. Available online at http://www.academicjournals.org/IJPS.ISSN 1992-1950 @2008 Academic Journals.

[4] Anomoharam O. (2011): Determination of ground water Potential in Asaba, Nigeria using surface geo-electric sounding Int. J. Physical Sci. 6: 7651-7656.

[5] Atakpo, E., and Ofomola, M.O. (2012): Hydro geologic investigation using vertical Electrical sounding method in Agbacha Otor, Delta State Nigeria J. Su-Environ, 11: $95-103$

[6] Ayoade, J.O. (1995): Hydrological Science bulletin, 20. 581-591. https://doi.org/10.1080/02626667509491589.

[7] Ehirim, C.N. and Ofor, W. (2011): Assessing aquifer vulnerability to contaminants near solid waste landfill sites in a coastal environment, Port Harcourt, Nigeria Trends Applied Sci. Res, 6: 165-173. https://doi.org/10.3923/tasr.2011.165.173.

[8] Ekine, A S., Osobonye (1996): Surface geo-electric sounding for the determination of Aquifer characteristics in parts of Bonny local government area of river state. Nigeria journal of physics, 85, pp 93-97.

[9] Ezeh, C.C. and Ugwu, G.Z. (2010): Geoelectric sounding for estimating groundwater potential in Nsukka LGA, Enugu State, Nigeria. Int. J. Phys. Sci. 5(5):415-420.3: 14-21. 
[10] Karani, B., Dhumal, K.N, Golabi, M. and Jaafarzadeh, N. (2009): Optimizating the relationship between water quality index and physical and chemical parameters of water in Bamdezh WetLand, Iran J. applied Sci., 9: 3900 -3905. https://doi.org/10.3923/jas.2009.3900.3905.

[11] Majumdar, R.K. and Das, D. (2011): Hydrological characterization and estimation of aquifer properties from electrical sounding data in Sagar Island region, South 24 Parganas, West Bengal, India. Asian J. Earth Sci., 4: 60-74. https://doi.org/10.3923/ajes.2011.60.74.

[12] Mbonu, D. D. C., Ebeniro, J. O., Ofoegbu, C. O. and Ekine, A. S. (1991): Geoelectrical sounding for determination of aquifer characteristics in of Umuahia area of Nigeria. Geophysics, 56 (5), 284-291. https://doi.org/10.1190/1.1443042.

[13] Mbipom, E. W., Okwueze, E. E. and Onwuegbuche, A. A. (1996): Estimation of aquifer transmissivity using VES data from the Mbaise area of Nigeria. Nigerian Journal of Physics, 3, 82 .

[14] Niwas, S. and Singhal, D.C. (1981): Estimation of Aquifer Transmissivity from Da-Zarrouk Parameters in Porous Media. Journal of Hydrology. 50:393-399. https://doi.org/10.1016/0022-1694(81)90082-2.

[15] Nwankwo, L. I. (2011): 2D Resistivity survey for ground water exploration in a hard rock terrain: A case study of MAGDAS observatory UNILORIN, Nigeria. Asian J. Earth Sci, 4: 46-53. https://doi.org/10.3923/ajes.2011.46.53.

[16] Nwosu, L.I., Ekine, A.S. and Nwankwo, C.N. (2013): Evaluation of Groundwater Potential from Pumping Test Analysis and Vertical Electrical Sounding Results: Case Study of Okigwe District of Imo State Nigeria. Pacific Journal of Science and Technology. 14(1):536-548.

[17] Olorunfemi, M.O., and Fasuyi, S.A. (1993): Aquifer types and the geoelectric hydrogeologic characteristics of parts of the central basement terrain of Nigeria, Niger State: Journal of African Earth Sciences, v. 16/3, p 309-317. https://doi.org/10.1016/0899-5362(93)90051-Q.

[18] Onyenechere, E. C. (2011): Effect of Rainfall Variability on Water Supply in Ikeduru L.G.A. of Imo State, Nigeria: International Multidisciplinary Journal, Ethiopia Vol. 5 (5), Serial No. 22, (Pp. 223-241). https://doi.org/10.4314/afrrev.v5i5.18.

[19] Onuoha, K.M. and Mbazi, F.C.C. (1988): Aquifer Transmissivity from Electrical Sounding Data of the Case of Ajali Sandstone Aquifers, South East of Enugu, Nig.”. In: C.O. Ofoegbu (ed.). Groundwater and Mineral Resources of Nig. Fried- vieweg \& Son Pub.: Berlin, Germany. 17-29. https://doi.org/10.1007/978-3-322-87857-1_3.

[20] Onwuegbuche, A.A. (1993): Geoelectrical investigations in the Imo River Basin Nigeria. Unpublished Ph.D thesis. Department of Physics, University of Calabar, pp. 2-62.

[21] Todd, D.K. (2004): Groundwater Hydrology $2^{\text {nd }}$ Edition John Wiley and Sons, New York.

[22] Uma, K.O. (1989): An appraisal of the groundwater resources of the Imo River Basin, Nigeria. Journal of Mining and Geology Vol. 25 Nos 1\&2, pp.305-31. 